\title{
Mule Deer Preference and Monoterpenoids (Essential Oils)
}

\author{
BRUCE L. WELCH, E. DURANT MCARTHUR, AND JAMES N. DAVIS
}

\begin{abstract}
Wild wintering mule deer browsed on a uniform shrub garden near Helper, Utah.' On this garden, 21 accessions from 5 A rtemisia taxa were selected to test the relationship between deer preference for these accessions and the amount of monoterpenoids present in the accessions. Deer preferences were determined by measuring removal of current year's growth. Samples of current year's growth (leaves and stems with terminal buds) were collected at the time preference measurements were taken to determine monoterpenoid content. Deer use ranged from zero to $83 \%$ of the current year's growth. Total monoterpenoid content among accessions varied from 0.75 to $3.62 \%$ of dry matter. Coefficients of determination, preference versus monoterpenoid levels (total and individual) ranged from 0 to $18 \%$. The monoterpenoid content of various accessions of Artemisia taxa was not significantly related to deer preference.
\end{abstract}

Because of the bacteriostatic and bactericidal properties of monoterpenoids (essential oils), a number of workers became concerned about possible adverse effects monoterpenoid-producing plants might have on ruminant digestion through suppressing rumen microorganisms. Nagy et al. (1964), Oh et al. (1967), Nagy and Tengerdy (1968), and Schwartz et al. (1980a) have reported in vitro evidence that monoterpenoids, when in high enough concentrations, do suppress activities of rumen microorganisms. From these reports the following hypotheses have emerged: (1) when big sagebrush exceeds $15-30 \%$ of the diet, ruminant digestion will be adversely affected (Wallmo and Regelin 1981); (2) the "theoretical" decline of mule deer in the western United States may be due to high (over 15-30\%) big sagebrush consumption (Dietz and Nagy 1976); and (3) mule deer selected monoterpenoid-containing forage plants with the least amount of monoterpenoids (Nagy and Tengerdy 1968, Schwartz et al. 1980b, Wallmo and Regelin 1981).

The third hypothesis, monoterpenoid content versus preference, is the subject of this study. During digestibility trials, Smith (1950) noted that penned deer showed definite aversion to individual big sagebrush plants. Mule deer preference for certain accessions and/or individual plants of big sagebrush has been observed in the field by a number of researchers (McArthur et al. 1979, Sheehy and Winward 1981, Welch et al. 1981). Welch et al. (1981) demonstrated differential preference of wintering mule deer for accessions of big sagebrush grown on a uniform garden. A few attempts have been made to relate monoterpenoid content to preference (Sheehy 1975, Scholl et al. 1977, Radwan and Crouch 1978, Schwartz et al.

\footnotetext{
Welch and McArthur are principal research plant physiologist and principal research plant geneticist, respectively, with the USDA, Forest Service, Intermountain Forest and Range Experiment Station, Shrub Sciences Laboratory, Provo, Utah 84601; Davis is wildlife research biologist with the Utah Division of Wildlife Resources, Shrub Sciences Laboratory, Provo (W-82-R, Job 1).

Manuscript received April 7, 1982.

IThe shrub garden at the Gordon Creek Wildlife Management area near Helper, Utah, is cooperatively maintained by the Utah State Division of Wildlife Resources (W-82R, Job 1) and the Intermountain Forest and Range Experiment Station.

${ }^{2}$ A number of studies have been reported that challenge the idea that big sagebrush monoterpenoids (essential oils) suppress microbial digestion (Smith 1950, 1952, 1957 Sheehy 1975, Welch and McArthur 1979, Tueller 1979, Connolly et al. 1980, Kufeld et al. 1981, Narjisse 1981, Welch and Pederson 1981, Cluff et al. 1982. Pederson and Welch 1982, White et al. 1982a).
}

1980b, Narjisse 1981, White et al. 1982b). Results of these studies fall into two categories: (1) monoterpenoids adversely influence preference (Schwartz et al. 1980b, Narjisse 1981-goats), and (2) monoterpenoids have little influence on preference (Scholl et al. 1977, Radwan and Crouch 1978, Narjisse 1981-sheep, White et al. 1982b). With this conflict in mind, we undertook this study to determine wintering mule deer preference for accessions of Artemisia taxa grown on a uniform garden as related to monoterpenoid content.

\section{Materials and Methods}

From a uniform shrub garden located near Helper, Utah, we selected 21 accessions of sagebrush to determine the relationship between wild mule deer preference for these accessions and monoterpenoid content. The following species and subspecies of sagebrush were represented in the study: Artemisia tridentata ssp. tridentata (basin big sagebrush), A.t. ssp. vaseyana (mountain big sagebrush), $A$. nova (black sagebrush), $A$. arbuscula (low sagebrush), and $A$. cana (silver sagebrush). In all, 21 accessions from various Utah and Nevada sites were chosen (Table 1). For each accession, 5 plants were randomly selected to determine mule deer preference and monoterpenoid content. We expressed preference of mule deer for the various accessions as a percent of current year's growth (vegetative stems and leaves) used.

Methodology used to measure forage used has been described elsewhere (Welch et al. 1981). Basically, it consists of prebrowsing and postbrowsing measurements. The prebrowsing measurements were made on November 20,1980. By December 17, 1980, 4 of the 21 accessions had already received heavy deer usage. Any additional use on these 4 accessions would have resulted in current year's growth with terminal buds being unavailable for use in determining monoterpenoid content. On December 18, 1980, we took the postbrowsing measurements and vegetative samples needed for running the monoterpenoid determinations. As suggested by Nichols (1973) all samples were collected within a 90minute period (10-11:30 a.m.). We removed the same type of tissue from plants as was removed by deer, namely, the terminal buds, and corresponding length of twigs with leaves $(4 \mathrm{~cm})$. For the 10 accessions that had not received any use, we sampled the first $4 \mathrm{~cm}$ of the twigs from terminal buds (leaves and stems). Samples collected from a given accession were pooled and frozen on-site with liquid nitrogen and transported in dry ice to laboratory freezers. Sample preparation, extraction, and monoterpenoid determinations have been described elsewhere (Welch and McArthur 1981).

Data were expressed as percent used (preference) and as percent of dry matter (monoterpenoid content). Correlation analysis, factor analysis, principal components, and multiple regressions were used to measure the relationship between preference and monoterpenoid content (total and individual).

\section{Results}

Deer consumed 0 to $83 \%$ of the current year's growth among 21 accessions of sagebrush (Table 2). The relationship between wintering mule deer preference for accessions of sagebrush and mono- 
terpenoid content is given in Table 2 .

Correlation coefficients ranged from 0-43\%. Correspondingly, coefficients of determination ranged from $0-18 \%$. We found no significant relationship between preference and monoterpenoid content with factor analysis, principal components analysis, or multiple regression.

\section{Discussion}

Other attempts have been made to relate monoterpenoid content to animal preference. Sheehy (1975) reported that the relative concentration of 8 monoterpenoids could account for $90 \%$ of the variation in mule deer utilization among 7 sagebrush taxa. Scholl et al. (1977), however, using relative concentration of 8 monoterpenoids could only account for $20.7 \%$ of the variation in wild mule deer preference for 12 sagebrush taxa. Radwan and Crouch (1978) found that "families of Douglas-fir" varied significantly in yield and composition of monoterpenoids, but differences were not related to black-tailed deer preference. White et al. (1982b) using pygmy rabbits (Brachylagus idahoensis) as test animals reported no significant relationship between grams of big sagebrush eaten and monoterpenoid content ( $r^{2}$ values ranged from $0-12 \%$ ). In a test to determine the influence of the odor of monoterpenoids on food preference in sheep and goats, Narjisse (1981) found that, for the first 2 days of the trial, sheep ate more food from feed bins lacking monoterpenoids. Selection after the first 2 days was random. Goats did not discriminate against monoterpenoid odor. Next, Narjisse tested to determine if a nosmic sheep and goats would discriminate against the taste of monoterpenoids. He mixed monoterpenoids with pelleted feed and gave his animals a choice between pellets with and without monoterpenoids. Goats discriminated against the taste of monoterpenoids, sheep did not.

The strongest evidence that monoterpenoids influence animal
Table 1. Acquisition location of 21 accessions of sagebrush grown on a uniform garden.

\begin{tabular}{lll}
\hline \hline Species and subspecies & Accession & County and state \\
\hline Artemisia tridentata ssp. tridentata & Indianola & Sanpete, Utah \\
& Oman & Carbon, Utah \\
lvie Creek & Sevier, Utah \\
Unknown source & \\
Artemisia tridentata ssp. vaseyana & Hobble Creek & Utah, Utah \\
& East Austin & Lander, Nevada \\
& Colton & Utah, Utah \\
& Austin & Lander, Nevada \\
Monticello & San Juan, Utah \\
& Spanish Valley & Grand, Utah \\
Milford & Beaver, Utah \\
& & \\
& Manti & Sanpete, Utah \\
Artemisia nova & Black Mountain & Sevier, Utah \\
& Spring Valley & White Pine, Nev. \\
& Pine Valley & Millard, Utah \\
Mayfield & Sanpete, Utah \\
& & \\
Artemisia cana & Salina & Sevier, Utah \\
& Paradise & Humboldt, Nevada \\
& Austin & Lander, Nevada \\
& Indian Peaks & Beaver, Utah \\
& & \\
& Soldier's Summit & Wasatch, Utah \\
\hline
\end{tabular}

Table 2. The relation between mule deer preference for accessions of 5 taxons of Artemisia grown in a uniform garden and the monoterpenoid content of the accessions. The relation between preference and monoterpenoid content is expressed as correlation coefficients ( $r$ ) and as coefficients of determination $\left(r^{2}\right)$. Mule deer preference expressed as a percent of current year growth eaten. Monoterpenoid content expressed as a percent of dry matter. Note, that not all monoterpenoids found in the accessions are listed (remaining data on file at the Shrub Sciences Laboratory; 735 North 500 East; Provo, Utah 84601).

\begin{tabular}{|c|c|c|c|c|c|}
\hline $\begin{array}{l}\text { Accessions of } \\
\text { Artemisia taxa }\end{array}$ & $\begin{array}{c}\text { Total } \\
\text { monoterpenoids }\end{array}$ & $\alpha$-Thujone & $\beta$-Thujone & Camphor & $\%$ Used \\
\hline $\begin{array}{l}\text { Indianola-t* } \\
\text { Unknown-t } \\
\text { Oman-t } \\
\text { Ivie Creek-t }\end{array}$ & $\begin{array}{l}1.08 \\
3.62 \\
1.41 \\
1.27\end{array}$ & $\begin{array}{l}0.09 \\
0.00 \\
1.21 \\
0.00\end{array}$ & $\begin{array}{l}0.27 \\
0.27 \\
0.04 \\
0.00\end{array}$ & $\begin{array}{l}0.03 \\
0.00 \\
0.12 \\
0.07\end{array}$ & $\begin{array}{l}00 \\
00 \\
00 \\
00\end{array}$ \\
\hline $\begin{array}{l}\text { Hobble Creek-v } \\
\text { East Austin-v } \\
\text { Colton-v } \\
\text { Austin-v } \\
\text { Monticello-v } \\
\text { Spanish Valley-v } \\
\text { Milford-v }\end{array}$ & $\begin{array}{l}2.21 \\
2.48 \\
1.82 \\
2.18 \\
0.89 \\
1.67 \\
2.45\end{array}$ & $\begin{array}{l}0.00 \\
1.27 \\
0.00 \\
0.01 \\
0.00 \\
0.00 \\
0.00\end{array}$ & $\begin{array}{l}0.16 \\
0.05 \\
0.32 \\
0.17 \\
0.00 \\
0.00 \\
0.00\end{array}$ & $\begin{array}{l}1.04 \\
0.00 \\
0.39 \\
0.37 \\
0.20 \\
0.23 \\
1.25\end{array}$ & $\begin{array}{l}83 \\
57 \\
83 \\
40 \\
57 \\
67 \\
69\end{array}$ \\
\hline $\begin{array}{l}\text { Salina-a } \\
\text { Paradise-a } \\
\text { Austin-a } \\
\text { Indian Peaks-a }\end{array}$ & $\begin{array}{l}0.97 \\
1.09 \\
1.36 \\
1.14\end{array}$ & $\begin{array}{l}0.00 \\
0.00 \\
0.00 \\
0.00\end{array}$ & $\begin{array}{l}0.76 \\
0.00 \\
0.00 \\
0.00\end{array}$ & $\begin{array}{l}0.06 \\
0.00 \\
0.30 \\
0.19\end{array}$ & $\begin{array}{l}15 \\
21 \\
00 \\
56\end{array}$ \\
\hline Soldier-c & 2.72 & 0.00 & 0.00 & 0.00 & 00 \\
\hline $\begin{array}{l}\text { Manti-n } \\
\text { Black Mountain-n } \\
\text { Spring Valley-n } \\
\text { Pine Valley-n } \\
\text { Mayfield-n }\end{array}$ & $\begin{array}{l}1.05 \\
1.17 \\
0.75 \\
1.22 \\
2.27\end{array}$ & $\begin{array}{l}0.00 \\
0.00 \\
0.00 \\
0.00 \\
0.00\end{array}$ & $\begin{array}{l}0.00 \\
0.00 \\
0.00 \\
0.00 \\
0.05\end{array}$ & $\begin{array}{l}0.39 \\
0.45 \\
0.45 \\
0.43 \\
0.63\end{array}$ & $\begin{array}{l}00 \\
00 \\
00 \\
48 \\
00\end{array}$ \\
\hline$r$ & 0.14 & 0.00 & 0.01 & 0.43 & - \\
\hline$r^{2}$ & 0.02 & 0.00 & 0.00 & 0.18 & - \\
\hline
\end{tabular}


preference comes from Schwartz et al. (1980b), who used tame mule deer as test animals in cafeteria feeding trials. The trials were designed to determine preference for 3 species of juniper and for pelleted feed treated with different levels of monoterpenoids. Their results showed that tame mule deer preferred feed that had the lowest levels of oxygenated monoterpenoids. Barbar et al. (1969) reported that sagegrouse selected sagebrush containing the lowest concentrations of monoterpenoids.

Thus, 3 studies (Barbar et al. 1969, Schwartz et al. 1980b, Narjisse 1981-goats) have supported the contention that monoterpenoid levels influence test animal preference and 5 studies (Scholl et al. 1977, Radwan and Crouch 1978, Narjisse 1981-sheep, White et al. 1982, this study) did not. It may be in the case of cafeteria trials by Schwartz et al. (1980b) and Narjisse (1981-goats), where all other factors were held constant, that monoterpenoids significantly influenced preference and that under field conditions in our study, monoterpenoid influences were masked by other factors.

One of these other factors could be animal experience. Zimmerman (1980) reporting on cattle on shrub ranges in Nevada noted that it is important that calves stay with their mothers to learn how to survive on shrub ranges. Without this experience, it would be doubtful that calves could survive on shrub diets. Narjisse (1981) in range tests reported that experienced range sheep consumed significantly higher levels of big sagebrush than inexperienced sheep. Carpenter et al. (1979) found that tame mule deer also increased big sagebrush consumption over time. Unknown animal factors may play as important a role in preference as plant factors do.

In summary, our study shows that monoterpenoid content of the various accessions of Artemisia taxa was not significantly related to deer preference.

\section{Literature Cited}

Barbar, T.A., J.G. Nagy, and T.A. May. 1969. Nutrition and dietary preference of penned sage grouse. Proc. 6th Bienn. West. States Sagegrouse Workshop, p. 180-186.

Carpenter, L.H., O.C. Wallmo, and R.B. Gill. 1979. Forage diversity and dietary selection by wintering mule deer. J. Range Manage. 32:226-229.

Cluff, L.K., B.L. Welch, J.C. Pederson, and J.D. Brotherson. 1982. Concentration of monoterpenoids in the rumen ingesta of wild mule deer. $J$. Range Manage. 35:192-194.

Connolly, G.E., B.O. Ellison, J.W. Fleming, S. Geng, R.E. Kepner, W.M. Longhurst, J.H. Oh, and G.F. Russell. 1980. Deer browsing of Douglasfir trees in relation to volatile terpene composition and in vitro fermentability. Forest Sci. 26:179-193.

Dietz, D.R., and J.G. Nagy. 1976. Mule deer nutrition and plant utilization. p. 71-78. In: G.W. Workman and J.B. Low (eds.). Mule deer decline in the West: A symp. Coll. Natur. Resour., Utah Agr. Exp. Sta., Logan.

Kufeld, R.C., M. Stevens, and D.C. Bowden. 1981. Winter variation in nutrient and fiber content and in vitro digestibility of Gambel oak (Quercus gambellii) and big sagebrush (Artemisia tridentata) from diversified sites in Colorado. J. Range Manage. 34:149-151.

McArthur, E.D., A.C. Blauer, A.P. Plummer, and R. Stevens. 1979. Characteristics and hybridization of important intermountain shrubs. IIl. Sunflower family USDA, Forest Serv., Res. Pap. INT-220, 82 p. Intermt. Forest and Range Exp. Sta., Ogden, Utah.

Nagy, J.G., H.W. Steinhoff, and G.W. Ward. 1964. Effects of essential oils of sagebrush on deer rumen microbial function. J. Wildl. Manage. 28:785-790.
Nagy, J.G., and R.P. Tengerdy. 1968. Antibacterial action of essential oils of Artemisia as an ecological factor. I1. Antibacterial action of volatile oils of Artemisia tridentata (big sagebrush) on bacteria from rumen of wild mule deer. Appl. Microbiol. 16:441-444.

Narjisse, H. 1981. Acceptability of big sagebrush to sheep and goats: Role of monoterpenes. Ph.D. Diss. Utah State Univ., Logan. 122 p.

Nicholas, H.J. 1973. Terpenes. p. 254-309. In: L.P. Miller (ed.) Phytochemistry, Vol. 11. Organic metabolites. Van Nostrand Reinhold Co., New York.

Oh, H.K., T. Sakai, M.B. Jones, and W.M. Longhurst. 1967. Effects of various essential oils isolated from Douglas-fir needles upon sheep and deer rumen microbial activity. Appl. Microbiol. 15:777-789.

Pederson, J.C., and B.L. Welch. 1982. Effects of monoterpenoid exposure on ability of rumen inocula to digest a set of forages. J. Range Manage. 35:500-502.

Radwan, M.A., and G.L. Crouch. 1978. Selected chemical constituents and deer browsing preference of Douglas-fir. J. Chem. Ecol. 4:675-683.

Scholl, J.P., R.G. Kelsey, and F. Shafizadeh. 1977. Involvement of volatile compounds of Artemisia in browse preference by mule deer. Biochem. System and Ecol. 5:291-295.

Schwartz, C.C., J.G. Nagy, and W.L. Regelin. 1980a. Juniper oil yield, terpenoid concentration, and antimicrobial effects on deer. J. Wildl. Manage. 44:107-113.

Schwartz, C.C., W.L. Regelin, and J.G. Nagy. 1980b. Deer preference for juniper forages and volatile oil treated foods. J. Wildl. Manage. 44:114120.

Sheehy, D.P. 1975. Relative palatability of seven Artemisia taxa to mule deer and sheep. M.S. Thesis, Oregon State Univ., Corvallis.

Sheehy, D.P., and A.H. Winward. 1981. Relative palatability of seven Artemisia taxa to mule deer and sheep. J. Range Manage. 34:397-399.

Smith, A.D. 1950. Sagebrush as winter feed for mule deer. J. Wildl. Manage. 14:285-289.

Smith, A.D. 1952. Digestibility of some native forages for mule deer. J. Wildl. Manage. 16:309-312.

Smith, A.D. 1957. Nutritive value of some browse plants in winter. J. Range Manage. 10:162-164.

Tueller, P.T. 1979. Food habits and nutrition of mule deer on Nevada ranges. Nevada Agr. Exp. Sta., Univ. Nevada, Reno.

Wallmo, O.C., and W.L. Regelin. 1981. Rocky Mountain and Intermountain habitats. Part 1. Food habits and nutrition. p. 387-398. In: O.C. Wallmo (ed.). Mule and black-tailed deer of North America. A wildlife management institute book. Univ. Nebraska Press, Lincoln.

Welch, B.L., and E.D. McArthur. 1979. Feasibility of improving big sagebrush (Artemisia) for use on mule deer winter ranges. p. 451-473. In: J.R. Goodin and D.K. Northington (eds.). Arid Land Plant Resources, Inter. Center for Arid and Semi-arid Land Studies. Texas Tech. Univ., Lubbock, $724 \mathrm{p}$.

Welch, B.L., and E.D. MeArthur. 1981. Variation of monoterpenoid content among subspecies and accessions of $A$ rtemisia tridentata grown in a uniform garden. J. Range Manage. 34:380-384.

Welch, B.L., and J.C. Pederson. 1981. In vitro digestibility among accessions of big sagebrush by wild mule deer and its relationship to monoterpenoid content. J. Range Manage. 34:497-500.

Welch, B.L., E.D. McArthur, and J.N. Davis. 1981. Differential preference of wintering mule deer for accessions of big sagebrush and for black sagebrush. J. Range Manage. 34:409-411.

White, S.M., B.L. Welch, and J.T. Flinders. 1982a. Monoterpenoid content of pygmy rabbit stomach ingesta. J. Range Manage. 35:107-109.

White, S.M., J.T. Flinders, and B.L. Welch. 1982b. Preference of pygmy rabbits, Brachylagus idahoensis, for various populations of big sagebrush, Artemisia tridentata. J. Range Manage. 35:724-726.

Zimmerman, E.A. 1980. Desert ranching in central Nevada. Rangelands 2:184-186 